\title{
Impact of Soil Moisture on Crop Yields in Major Rainfed Growing Regions of Peninsular India
}

\section{Santanu Kumar Bal ( $\nabla$ santanu.bal@icar.gov.in )}

ICAR-Central Research Institute for Dryland Agriculture (CRIDA)

\section{H. S. Shivaramu}

UAS

P. Vijaya Kumar

ICAR-Central Research Institute for Dryland Agriculture (CRIDA)

H. Lingaraj

UAS

\section{M. Sandeep}

ICAR-Central Research Institute for Dryland Agriculture (CRIDA)

\section{A. V.M. Subba Rao}

ICAR-Central Research Institute for Dryland Agriculture (CRIDA)

\section{K. Singh}

ICAR-Central Research Institute for Dryland Agriculture (CRIDA)

\section{H. Manjunatha}

UAS

S. N. Malleswari

ANGRAU Agricultural Research Station

\section{Arvind Tupe}

PDKV

\section{G. Sudhakar}

TNAU Agricultural Research Station

\section{K. K. Dakhore}

VNMKV

\section{S. Subbulakshmi}

TNAU Agricultural Research Station

\section{Research Article}

Keywords: Soil Moisture, Crop Yields, Rainfed Growing Regions, water stressed regions

Posted Date: July 7th, 2021

DOI: https://doi.org/10.21203/rs.3.rs-653972/v1 
License: (우 This work is licensed under a Creative Commons Attribution 4.0 International License. Read Full License 


\section{Abstract}

Assessment of soil moisture availability and timely declaration of drought are keys for exemplary relief assistance in water stressed regions. Percent available soil moisture (PASM) is one among several drought declaration indices, needs evaluation with respect to individual crop and cropping system, as the amount of water requirement varies with respect to crop and its growth stage. Analysis of yield variability due to PASM was carried out by employing correlation and linear regression analyses based on long term observations in experiments conducted at different dry farming locations of the peninsular India. The range of available soil moisture in order to obtain at least 50 per cent of optimum yield in cereals (maize: 26 and finger millet: 52.9 PASM), pulses (pigeonpea: 37.2 PASM), oilseeds (soybean: 26.8 to 30.5 , groundnut: 53.8 to 61.7 PASM) and commercial crops (cotton: 26.3 PASM) was 26 to 61 per cent. Establishment of these regression models helped in timely drought declaration / precise identification of drought hit areas and assuring feasible relief assistance. The outcomes of the study may be used for amending the existing drought norms $(0-50$; severe, $50-75$; mild and 75-100; no drought) for provision of proportionate compensations to the farmers.

\section{Introduction}

One-third of the population of the world lives in regions stressed by water. With changes in climatic pattern and frequent global warming in recent decades, the hydrological regimes in which crops were grown have been getting altered and hence affecting crop growth ${ }^{1}$. Water availability is a significant cause of variability in crop yields in many conditions ${ }^{2}$. Changes in seasonal and intra seasonal precipitation pattern affect the soil water regime. Precipitation is recognised globally as a leading factor affecting, in particular, the yield of rainfed crops ${ }^{3}$. The Indian sub-continent experiences large-scale drought in some part or the other, almost every year ${ }^{4}$. Drought occurs in nearly all climatic zones of the world at one time or other, but this creeping phenomenon mostly affects the tropics and adjoining regions ${ }^{5}$.

The India Meteorological Department defines meteorological drought in any area when the rainfall deficiency in that area is more or equal to $26 \%$ of long term normal (https://mausam.imd.gov.in/imd_latest/monsoonfaq.pdf). It is further classified in to moderate and (26-50\% deficient) severe drought ( $>50 \%$ deficient) depending upon the rainfall. A period of drought is defined as a year or season in which the total rainfall received is less than $75 \%$ of the normal ${ }^{6}$. The 'Drought Declaration' means the beginning of the government's response to circumstances that reflect a situation of drought. The decision to declare drought over a designated administrative unit level (District / Taluka / Tehsil / Block / Gram Panchayat) should be directed and made without undue delay by objective criteria, so that relief assistance and concessions can be given in time to the citizens affected by drought ${ }^{7}$. Five categories of indices are recommended for developing a monitoring matrix for drought in India by Government of India ${ }^{8}$. They are, rainfall related indices viz., Palmer Drought Severity Index (PDSI) ${ }^{9}$, Deciles ${ }^{10}$, Surface Water Supply Index (SWSI) ${ }^{11}$, Standardized Precipitation Index (SPI) ${ }^{12}$, Effective Drought Index (EDI) ${ }^{13}$, Reconnaissance Drought Index (RDI) ${ }^{14}$, Standardized Precipitation Evapotranspiration Index (SPEI) $)^{15}$ and so on, remote sensing-based vegetation indices viz., Normalized Difference Vegetation Index (NDVI) ${ }^{16}$, Normalized Difference Water Index (NDWI) ${ }^{17}$, Shortwave Angle Slope Index (SASI) ${ }^{18}$ etc; crop situation related indices (area under sowing), soil moisture-based indices viz., 
Percent Available Soil Moisture (PASM), Moisture Adequacy Index(MAI) etc and hydrological indices viz., Reservoir Storage Index (RSI), Groundwater Drought Index (GDI), Stream-Flow Drought Index(SFDI) and so on.

In many environments, water supply is a major source of variability in crop yields ${ }^{2}$. Deficit precipitation affect crop yields, especially if either rainfall doesn't occur in time or dry periods occur during critical development stages. Moisture stress during the flowering, pollination, and grain-filling stages is especially harmful to maize ${ }^{19}$, soybean ${ }^{20}$, wheat ${ }^{21}$ and sorghum ${ }^{22}$. Available soil moisture is a very relevant indicator of drought, especially in rainfed regions ${ }^{23}$. Soil-moisture balance technique may be used to measure the soil moisture-based indices, which includes gathering some of the base-line data related to soil properties, climate parameters and pattern of crop growth ${ }^{24}$. Basically, soil moisture balance measures the amount of rainfall accessible to crops depending upon crop water requirement, climatic evaporative demand and soil water holding capacity 25,6 . In the latest revision brought out by Government of India ${ }^{8}$, PASM was included as one of the parameters for drought declaration protocol. Hence, we have attempted to arrive at the relationships between soil moisture availability with growth and yield of major rainfed crops in various locations of peninsular (central and southern) India. The results or outcome of this study, will be helpful in revising the drought declaration criteria based on the real-time field level soil moisture and expected reduction in crop yield due to lower soil moisture levels.

\section{Results}

\section{- Relationship between soil moisture and crop yield}

Correlations between soil moisture and crop yield of individual crop revealed that, there is a significant positive correlation between these two parameters in each crop (Table 1). The magnitude of relationship is up to 0.98 in crops like maize and as low as 0.66 in soybean. This is because, the sensitivity of crops to soil moisture deficit vary from crop to crop and also with stages. Further, the soil water regime is affected by changes in seasonal soil moisture availability, and inter-annual variation of the same due to respective variability in the precipitation ${ }^{3}$. 
Table 1

Correlation between percent available soil moisture and crop yields under different sowing dates at different locations. D1, D2, D3 and D4 are dates of sowing of crops, varied for each experimental set-up. ** Correlation is significant at $p=0.01$ *

Correlation is significant at $\mathrm{p}=0.05,{ }^{\mathrm{NS}}$ Correlation is non-significant.

\begin{tabular}{|c|c|c|c|c|c|}
\hline \multirow[t]{2}{*}{ Crop/Location } & \multicolumn{5}{|c|}{ Date of sowing\# } \\
\hline & D1 & D2 & D3 & D4 & Mean \\
\hline Soybean (Akola) & $0.62^{N S}$ & $0.63^{N S}$ & $0.69^{N S}$ & $1.00 * \star$ & $0.66^{*}$ \\
\hline Groundnut (Ananthapuramu) & $0.96 *$ & $0.92^{N S}$ & $0.87^{N S}$ & NA & $0.68^{\star}$ \\
\hline Cotton (Parbhani) & $0.96 * \star$ & $0.94 * \star$ & $0.94 * \star$ & $0.93^{\star \star}$ & $0.94 * \star$ \\
\hline Pigeonpea (Bangalore) & $1.00 *$ & $0.99 * *$ & $0.98^{*}$ & $0.94^{N S}$ & $0.94^{\star *}$ \\
\hline Soybean (Parbhani) & NA & NA & NA & NA & $0.94^{\star *}$ \\
\hline Maize (Kovilpatti) & NA & NA & NA & NA & $0.98 * *$ \\
\hline Groundnut (Bangalore) & NA & NA & NA & NA & $0.96 * \star$ \\
\hline Finger millet (Bangalore) & NA & NA & NA & NA & $0.92^{\star *}$ \\
\hline
\end{tabular}

\section{- Influence of PASM on yield of different crops}

\section{Maize}

Maize is highly susceptible to atmospheric stresses during the initial stages of reproduction viz., silking, and blistering. Water and heat stress can significantly limit the ability of maize to properly pollinate ${ }^{26}$. During subsequent reproductive stages, the maize kernels are still small, but water constitutes about $85 \%$ or the kernels mass, which is the highest over the growing cycle. During milk, dough, and dent stages, the kernel size significantly increases; however, the amount of water decreases to about $55 \%$ of the kernel, further dropping to $30 \%$ by maturity. Stress during the late reproductive stages impacts dry matter accumulation ${ }^{27}$. Hence, it is helpful to understand the variability in growth and yield of maize under water limiting situations in peninsular India. Outcome of the studies carried out at Kovilpatti of Tamil Nadu in India indicated that, the available soil moisture and yields were positively correlated with $\mathrm{R}^{2}$ value of 0.98 . The effect of low moisture during reproductive stage is more as compared to vegetative and maturity stages, i.e. severe drought during reproductive stage has produced $3209 \mathrm{~kg} / \mathrm{ha}$ yield as compared to that produced due to drought in vegetative and maturity stages (3385 and $3216 \mathrm{~kg} / \mathrm{ha}$, respectively) (Table $2 \&$ Fig. 1). 
Table 2

Influence of PASM in different growth stages on yield of maize at

Kovilpatti, Tamil Nadu.

\begin{tabular}{|c|c|c|c|}
\hline Growth stage & Drought category & PASM (\%) & Yield (kg/ha) \\
\hline \multirow[t]{4}{*}{ Vegetative } & Severe & 4.7 & 3385 \\
\hline & Moderate & 39.5 & 4748 \\
\hline & Mild & 59.4 & 5521 \\
\hline & No & - & - \\
\hline \multirow[t]{4}{*}{ Reproductive } & Severe & 3.6 & 3209 \\
\hline & Moderate & 38.2 & 4675 \\
\hline & Mild & 62.0 & 5481 \\
\hline & No & - & - \\
\hline \multirow[t]{4}{*}{ Maturity } & Severe & 4.1 & 3216 \\
\hline & Moderate & 36.5 & 4488 \\
\hline & Mild & 59.0 & 5286 \\
\hline & No & 91.0 & 5824 \\
\hline
\end{tabular}

Water stress during vegetative stage will register a lower impact on maize yield compared to stress during early reproductive stages. There is a chance for $13.5 \%$ average reduction in maize yield when the stress occurred during vegetative stage while $53 \%$ reduction in yield occurred with the stress during reproductive stage $\mathrm{e}^{28}$. However, as discussed previously, the reduction in yield is a function of both the timing and duration of the water stress. Thus, prolonged drought during vegetative stage can be equally damaging ${ }^{29}$, when the observed yield reduction was $23 \%$ for a two-week long water stress period during reproductive period compared to $46 \%$ when the stress continued for a four-week event during vegetative period.

\section{Finger millet}

The finger millet crop being hardy and resistant to flood, drought, pests and disease is mainly grown in drylands of south India, whenever rainfall is not sufficient enough to cultivate other major crops. It is raised as a sequence crop of paddy, based on residual moisture. Even though it is a drought resistance crop, soil moisture variability during different growth stages majorly decides its yield levels. For identifying magnitude of soil moisture influence on yield, long term experiments were conducted at Bangalore. The results of this study showed that that finger millet yield is significant positive correlated with soil moisture ( $R^{2}$ value of 0.92$)$. The yield of the crop was as low as $0 \mathrm{~kg} / \mathrm{ha}$ under severe drought (20\% PASM) to $4236 \mathrm{~kg} / \mathrm{ha}$ under no drought situations (100\% PASM) (Fig. 2). Similar results of soil moisture effect on lead yield variability ${ }^{30}$ indicating significant effect ( $p<$ 0.028 ) of drought on finger millet yield.

\section{Soybean}

The soil moisture availability at different growth stages have influenced the yield of soybean at Parbhani (Table 3). The yield variation due to available soil moisture at different stages ranged from 135 to $1803 \mathrm{~kg} / \mathrm{ha}$. 
The effect of low moisture availability at vegetative and reproductive stage was greater than the effect that in maturity stage (Fig. 3).

For example, severe drought at vegetative and reproductive stages of the crop produced only 135 and $178 \mathrm{~kg} / \mathrm{ha}$ yield, respectively. However, the yield was $405 \mathrm{~kg} / \mathrm{ha}$ even though crop suffered from severe drought during maturity. The reason can be ascribed to well established root system as well as lower water requirement by the crop.

Correlation between PASM and yield under different sowing windows at Akola, showed yield increases with delay in sowing, i.e., magnitude of relation was as low as $0.62\left(R^{2}\right)$ for the crop sown in first week of July and 1.0 in last week of July (Table 4). Differences in correlation coefficients were mainly due to the soil properties of these regions. In typical black cotton soils at Akola, most of the first rainfall received was infiltrated into deeper layers of the soils through wide opened cracks in the previous summer. The rainfall analysis also indicated that there was higher rainfall in July $(223.3 \mathrm{~mm}$ with $40.6 \% \mathrm{CV})$ facilitating better soil moisture availability ${ }^{31}$.

Table 3

Influence of PASM in different growth stages and sowing environments on yield of soybean at Parbhani and Akola, Maharashtra.

\begin{tabular}{|c|c|c|c|c|c|c|c|}
\hline \multirow{2}{*}{$\begin{array}{l}\text { Growth } \\
\text { stage }\end{array}$} & \multicolumn{3}{|l|}{ Parbhani } & \multicolumn{4}{|l|}{ Akola } \\
\hline & $\begin{array}{l}\text { Drought } \\
\text { category }\end{array}$ & $\begin{array}{l}\text { PASM } \\
\%\end{array}$ & $\begin{array}{l}\text { Yield } \\
\text { (kg/ha) }\end{array}$ & $\begin{array}{l}\text { Sowing } \\
\text { window }\end{array}$ & $\begin{array}{l}\text { Drought } \\
\text { category }\end{array}$ & $\begin{array}{l}\text { PASM } \\
\%\end{array}$ & $\begin{array}{l}\text { Yield } \\
\text { (kg/ha) }\end{array}$ \\
\hline \multirow[t]{4}{*}{ Vegetative } & Severe & 13 & 135 & \multirow{4}{*}{$\begin{array}{l}\text { Jul 1st } \\
\text { week }\end{array}$} & Severe & 15 & 1312 \\
\hline & Moderate & 32 & 640 & & Moderate & 38 & 1370 \\
\hline & Mild & 61 & 1342 & & Mild & 64 & 2069 \\
\hline & No & 86 & 1769 & & No & 93 & 1659 \\
\hline \multirow[t]{4}{*}{ Reproductive } & Severe & 19 & 178 & \multirow{4}{*}{$\begin{array}{l}\text { Jul 2nd } \\
\text { week }\end{array}$} & Severe & 12 & 718 \\
\hline & Moderate & 39 & 771 & & Moderate & 37 & 1194 \\
\hline & Mild & 65 & 1200 & & Mild & 64 & 2069 \\
\hline & No & 92 & 1684 & & No & 99 & 1508 \\
\hline \multirow[t]{6}{*}{ Maturity } & Severe & 16 & 405 & \multirow{4}{*}{$\begin{array}{l}\text { Jul 3rd } \\
\text { week }\end{array}$} & Severe & 15 & 812 \\
\hline & Moderate & 27 & 1044 & & Moderate & 37 & 1088 \\
\hline & Mild & 67 & 995 & & Mild & 57 & 1597 \\
\hline & No & 87 & 1803 & & No & 95 & 1267 \\
\hline & & & & \multirow{2}{*}{$\begin{array}{l}\text { Jul 4th } \\
\text { week }\end{array}$} & Severe & 10 & 645 \\
\hline & & & & & Moderate & 33 & 1119 \\
\hline
\end{tabular}


The weekly PASM values across various sowing environments were categorized into various phenophases and the mean PASM and pod yield ( $\mathrm{kg} / \mathrm{ha}$ ) is worked out to study the impact of agricultural drought at various phenophases on pod yield of groundnut at Ananthapuramu (AP). The yield variability due to available soil moisture at different stages is in the range of 399 to $1999 \mathrm{~kg} / \mathrm{ha}$. The effect of low moisture availability at emergence, vegetative, pegging and pod development stage is higher as compared to that at flowering and pod maturity stages (Fig. 4).

Due to severe drought at emergence, vegetative, pegging and pod development stages, crop productivity was less viz., 399, 766, 867 and 661 kg/ha, respectively. However, even though crop suffered severe drought during flowering and maturity stages, it was able to achieve higher yields of 1147 and $970 \mathrm{~kg} / \mathrm{ha}$, respectively. Similar results were also observed in Bangalore, where available soil moisture influenced the groundnut yield with a correlation coefficient of 0.99 (Table 4). Therefore, higher soil moisture content resulted in higher pod yield as evident from the significant positive correlation between soil moisture content at different stages with pod yield. The correlation was more significant during the later stages of the crop. Overall soil moisture content during the total crop period was also significantly and positively correlated with pod yield ${ }^{32}$. 
Table 4

Influence of PASM in different growth stages and dates of sowing on yield of groundnut at Ananthapuramu and Bengaluru.

\begin{tabular}{|c|c|c|c|c|c|c|c|c|}
\hline \multirow[t]{2}{*}{ Growth stage } & \multicolumn{6}{|c|}{ Ananthapuramu } & \multicolumn{2}{|c|}{ Bangalore } \\
\hline & $\begin{array}{l}\text { Drought } \\
\text { class }\end{array}$ & $\begin{array}{l}\text { PASM } \\
(\%)\end{array}$ & $\begin{array}{l}\text { Yield } \\
\text { (kg/ha) }\end{array}$ & $\begin{array}{l}\text { Date of } \\
\text { sowing }\end{array}$ & $\begin{array}{l}\text { PASM } \\
(\%)\end{array}$ & $\begin{array}{l}\text { Yield } \\
\text { (kg/ha) }\end{array}$ & $\begin{array}{l}\text { PASM } \\
(\%)\end{array}$ & $\begin{array}{l}\text { Yield } \\
\text { (kg/ha) }\end{array}$ \\
\hline \multirow[t]{4}{*}{ Emergence } & Severe & 16 & 399 & \multirow{4}{*}{$\begin{array}{l}\text { July 1st } \\
\text { FN }\end{array}$} & 15 & 1051 & 49.0 & 419 \\
\hline & Moderate & 42 & 849 & & 39 & 1240 & 60.0 & 617 \\
\hline & Mild & - & - & & 65 & 1394 & 62.0 & 844 \\
\hline & No & 92 & 1680 & & 90 & 1908 & 78.0 & 1018 \\
\hline \multirow[t]{4}{*}{ Vegetative } & Severe & 15 & 766 & \multirow{4}{*}{$\begin{array}{l}\text { July 2nd } \\
\text { FN }\end{array}$} & 8 & 854 & 81.0 & 1261 \\
\hline & Moderate & 40 & 839 & & 35 & 1032 & 82.0 & 1308 \\
\hline & Mild & 59 & 1999 & & 59 & 1729 & 86.0 & 1640 \\
\hline & No & 99 & 1110 & & 98 & 1796 & 89.0 & 1800 \\
\hline \multirow[t]{4}{*}{ Flowering } & Severe & 10 & 1147 & \multirow{4}{*}{$\begin{array}{l}\text { Aug 1st } \\
\text { FN }\end{array}$} & 14 & 684 & 93.0 & 2084 \\
\hline & Moderate & 42 & 1494 & & 38 & 885 & 100.0 & 2245 \\
\hline & Mild & 64 & 1459 & & 62 & 924 & & \\
\hline & No & 100 & 1448 & & 88 & 939 & & \\
\hline \multirow[t]{4}{*}{ Pegging } & Severe & 12 & 867 & & & & & \\
\hline & Moderate & 34 & 1296 & & & & & \\
\hline & Mild & 58 & 1400 & & & & & \\
\hline & No & 95 & 1066 & & & & & \\
\hline \multirow{4}{*}{$\begin{array}{l}\text { Pod } \\
\text { Development }\end{array}$} & Severe & 8 & 661 & & & & & \\
\hline & Moderate & 36 & 962 & & & & & \\
\hline & Mild & 64 & 1435 & & & & & \\
\hline & No & 90 & 1517 & & & & & \\
\hline \multirow[t]{2}{*}{ Maturity } & Severe & 6 & 970 & & & & & \\
\hline & Moderate & 33 & 1464 & & & & & \\
\hline
\end{tabular}

\section{Cotton}

Cotton being one of the major commercial crops in drylands of India, gets affected by both intra and interseasonal droughts. The most discernible response due to soil moisture deficit across different stages of crop is a reduction in plant stature and other growth parameters. Keeping in view of these effects, study was conducted 
to understand the effect of available soil moisture under four sowing windows at Parbhani, a major cotton growing area of Maharashtra, India. Correlations between soil moisture and seed cotton yield is positive with a magnitude of $\mathrm{R}^{2}$ of 0.96 to 0.93 (Table 6) in early (June $2 \mathrm{FN}$ ) to late sown (August 1FN) conditions, respectively indicating a strong interrelationship between the two parameters (Fig. 5).

Drought in different crop stages showed varied impact on yield of crop sown under different sowing windows (Table 5). In each sowing window (June 2FN, July 1FN and July 2FN), severe drought at vegetative stage produced lower lint yields $(277,315$ and $267 \mathrm{~kg} / \mathrm{ha}$ lint yield) as compared to other two growth stages. Further, there was non-significant improvement in lint yield under severe drought both at reproductive and maturity stages since these stages coincide with high rainfall period (July) of the region. In addition to that, cotton is having deeper roots, can absorb moisture from deeper layers of typical vertisols of the region under moisture stress situation.

In case of late sown conditions (August), lowest lint yield was recorded due to severe drought at maturity stage $(428 \mathrm{~kg} / \mathrm{ha})$ as compared to vegetative $(514 \mathrm{~kg} / \mathrm{ha})$ and reproductive stages ( $456 \mathrm{~kg} / \mathrm{ha})$. This may be due to the inability of soil to supply enough moisture which might have been depleted to the maximal extent during earlier stages under less rainfall conditions. Adding to that, at earlier stages of the crop, it grows fully exploiting available moisture, depleting it for use in later stages leading to imbalance in source to sink relationship ending up with reduction in yield.

It was reported that, no severe impact of moisture deficit stress in the dryland plots had not become severe enough to impact on any of the growth parameters in early sown cotton ${ }^{33}$. However, in late sown crop, a severe moisture deficit stress was developed to impact most of the growth and yield parameters. There was significant difference in harvest index due to date of sowing (32\% lesser dry matter and $30 \%$ lesser $\mathrm{HI}$ in late sown situations than early sowing). 
Table 5

Influence of PASM in different growth stages and sowing windows on cotton yield (kg/ha) at Parbhani, Maharashtra.

\begin{tabular}{|c|c|c|c|c|c|c|c|c|c|}
\hline \multirow[t]{2}{*}{ Growth stage } & \multirow[t]{2}{*}{ Drought class } & \multicolumn{2}{|c|}{ June 2FN } & \multicolumn{2}{|c|}{ July 1FN } & \multicolumn{2}{|c|}{ July 2FN } & \multicolumn{2}{|c|}{ August 1FN } \\
\hline & & PASM & Yield & PASM & Yield & PASM & Yield & PASM & Yield \\
\hline \multirow[t]{4}{*}{ Vegetative } & Severe & 23.5 & 277 & 13.9 & 315 & 13.8 & 267 & 25.0 & 514 \\
\hline & Moderate & 37.8 & 753 & 39.1 & 738 & 39.8 & 722 & 42.1 & 858 \\
\hline & Mild & 62.7 & 1909 & 61.2 & 1791 & 62.2 & 1946 & 63.1 & 1645 \\
\hline & No & 88.8 & 3127 & 85.3 & 3397 & 93.5 & 3092 & 85.3 & 3397 \\
\hline \multirow[t]{4}{*}{ Reproductive } & Severe & 23.1 & 550 & 13.8 & 446 & 12.4 & 456 & 20.1 & 456 \\
\hline & Moderate & 38.2 & 788 & 36.2 & 872 & 34.7 & 779 & 35.9 & 793 \\
\hline & Mild & 63.4 & 1755 & 63.2 & 1681 & 62.5 & 1839 & 62.9 & 1721 \\
\hline & No & 83.6 & 2992 & 78.7 & 3221 & 83.3 & 2763 & 81.5 & 3221 \\
\hline \multirow[t]{3}{*}{ Maturity } & Severe & 9.4 & 473 & 10.3 & 456 & 11.1 & 439 & 14.4 & 428 \\
\hline & Moderate & 37.0 & 877 & 38.4 & 916 & 36.7 & 941 & 34.8 & 962 \\
\hline & Mild & 56.7 & 2315 & 53.1 & 2315 & 53.2 & 2550 & 51.8 & 2550 \\
\hline
\end{tabular}

\section{Pigeon pea}

Pigeon pea is being a long duration dryland crop, has capacity to extract moisture from the deeper soil layers.

But, rainfall acts as a major factor deciding the level of soil moisture in tropical countries like India, necessitates the study of influence of soil moisture on growth and yield of pigeon pea. PASM and yield relationship in pigeon pea presented in Table 6 and Fig. 6 indicates that the per cent increase in yield is high with the increase in PASM as a single factor above $50 \%$ PASM. Hence, PASM values of 45 per cent, the crop can yield only 50 per cent of the normal yield. PASM of less than 15 will lead to complete crop failure. In addition to that, from Fig. 6, the estimated pigeon pea seed yield was around $1000 \mathrm{~kg} / \mathrm{ha}$ when the PASM was 50, the yield levels were as low as $329 \mathrm{~kg} / \mathrm{ha}$ when the PASM was 25. 
Table 6

Influence of PASM under different sowing windows on pigeon pea

yield at Bangalore, Karnataka.

\begin{tabular}{|c|c|c|c|}
\hline Sowing window & Drought category & PASM (\%) & Yield (kg/ha) \\
\hline \multirow[t]{4}{*}{ May } & Severe & NA & NA \\
\hline & Moderate & 40 & 504 \\
\hline & Mild & 60 & 1393 \\
\hline & No & 83 & 2530 \\
\hline \multirow[t]{4}{*}{ June } & Severe & 20 & 323 \\
\hline & Moderate & 39 & 634 \\
\hline & Mild & 63 & 1237 \\
\hline & No & 86 & 1909 \\
\hline \multirow[t]{4}{*}{ July } & Severe & 23 & 348 \\
\hline & Moderate & 38 & 718 \\
\hline & Mild & 65 & 1079 \\
\hline & No & 87 & 1885 \\
\hline \multirow[t]{4}{*}{ August } & Severe & 18 & 202 \\
\hline & Moderate & 39 & 463 \\
\hline & Mild & 61 & 943 \\
\hline & No & 87 & 2509 \\
\hline
\end{tabular}

The PASM values in different stages of pigeon pea crop over all the sowing windows indicated that severe drought (<25 PASM) during pod filling stage has produced an average of $20 \%$ of the yield, while an average of $43 \%$ of the yield was obtained due to severe drought during flowering stage. Thus, optimum moisture at these stages is crucial for getting potential yield of the crop. The moisture stress at different growth stages of pigeon pea affected its yield levels. The pigeon pea seed yield was reduced by $37 \%$ due to moisture stress at flowering and pod filling stages and not significantly affected by stress at pod filling stage alone ${ }^{34}$. Earlier researches also indicated that the productivity of pigeon pea was more influenced by soil depth vis-à-vis moisture availability. The seed yield of pigeon pea was higher by 46 to 66 per cent in 20-40 cm soil depths over other lower soil depths ${ }^{35}$.

\section{- PASM requirements for production of $50 \%$ of the optimum yield in different crops}

Based on long-term experiments conducted at five locations over the years, regression relationships were developed between the PASM and crop yields (Table 7). These relationships can be exploited to estimate soil moisture level required to obtain at least $50 \%$ of the optimum yields. It can be perceivable from Table 8 that 
some crops even require 26 PASM to produce atleast $50 \%$ of the normal yield. In water intensive crops like pigeon pea and groundnut, the level will be 37 to 62 , respectively.

Table 7

Regression equations for relationship between crop yield and PASM along with PASM required for production of $50 \%$ of optimum yield. Yield levels obtained in farmers' fields and university experiments under non-stressed conditions.

\begin{tabular}{|c|c|c|c|c|c|}
\hline Crop & Regression equation & $\mathrm{R}^{2}$ & $\begin{array}{l}\text { Significance } \\
\text { (p) }\end{array}$ & $\begin{array}{l}50 \% \text { of } \\
\text { Optimum yield } \\
(\mathrm{kg} / \mathrm{ha})^{*}\end{array}$ & $\begin{array}{l}\text { PASM for } 50 \% \\
\text { of Optimum } \\
\text { yield }\end{array}$ \\
\hline Maize & $y=33.266 x+3259.3$ & 0.95 & $1.60678 \mathrm{E}-06$ & 4125 & 26.0 \\
\hline Finger millet & $y=43.083 x-966.77$ & 0.85 & 0.003405684 & 1312.5 & 52.9 \\
\hline $\begin{array}{l}\text { Soybean } \\
\text { (Parbhani) }\end{array}$ & $y=17.803 x+119.67$ & 0.89 & 0.010151947 & 625 & 30.5 \\
\hline Soybean (Akola) & $\begin{array}{l}y=-0.2861 x^{2}+40.243 x+ \\
310.2\end{array}$ & 0.70 & 0.00027 & 625 & 26.8 \\
\hline $\begin{array}{l}\text { Groundnut } \\
\text { (Ananthapuramu) }\end{array}$ & $\begin{array}{l}y=-0.0065 x^{3}+0.8593 x^{2} \\
-17.98 x+931.79\end{array}$ & 0.52 & 0.00737 & 437.5 & 61.7 \\
\hline $\begin{array}{l}\text { Groundnut } \\
\text { (Bangalore) }\end{array}$ & $y=36.68 x-1537.5$ & 0.93 & 8.45962E-06 & 437.5 & 53.8 \\
\hline Cotton & $y=38.605 x-325.98$ & 0.88 & 1.24399E-20 & 687.5 & 26.3 \\
\hline Pigeonpea & $y=29.418 x-469.79$ & 0.88 & $2.18881 \mathrm{E}-07$ & 687.5 & 37.2 \\
\hline
\end{tabular}

The yield of potato was influenced by soil moisture and rainfall to a greater extent than by nutrients ${ }^{36}$. The wheat yield was affected by average soil moisture during seed planting time, average temperature during flowering time and minimum precipitation during planting time ${ }^{37}$. It was also noticed that, soil moisture was the most important factor on wheat yield ${ }^{38}$.

\section{Discussions}

The study revealed that the yield is significantly influenced by Percent Available Soil Moisture (PASM)for six different crops. The PASM for obtaining $50 \%$ of optimum yield in cereals (maize: $26 \%$ and finger millet: $52.9 \%$ ), pulses (pigeon pea: $37.2 \%$ ), oilseeds (soybean: 26.8 to $30.5 \%$, groundnut: 53.8 to $61.7 \%$ ) and commercial crops (cotton: $26.3 \%$ ) ranged from 26 to 61 per cent. The criteria followed for considering < 25 PASM as severe drought as per the Drought Manual 2016 of Govt. of India norms needs to be modified in view of the findings of the present study.

The percent available soil moisture, though an important criterion for drought declaration, its applicability was overlooked because of the lack of understanding of its effect on individual crops at many locations is resulting unscientific drought declaration vis-a-vis its efficient management so far in the country. 
Present study highlighted the crop performance especially yield difference at soil moisture levels and crop stages. The study further paved the way for modifying the existing norms/ guidelines for drought declaration in the 'Drought manual-2016' published by Ministry of Agriculture and Farmers' Welfare, Gol. The amendments considered are; 0-50 PASM as severe, 50-75 as mild and 75-100 as no drought situation. The methodology is implemented at national level for the benefit of true drought affected farmers. This study clearly indicates the need for to look into the drought declaration norms presently being used for these crops. Indeed, the outcome of the present study along with its methodology was explained to stakeholders and policy makers in 2019 which helped to declare a greater number of taluks/blocks as drought hit as compared to traditional method of drought declaration in Karnataka. The same criteria may be followed by planners of other states to help the drought affected farmers in a better way.

\section{Methods}

\section{Study area}

Long-term experiments were conducted on predominant rainfed crops at 5 centres of All India Coordinated Research Project on Agrometeorology (AICRPAM), Indian Council of Agricultural Research, representing different soil and climatic conditions. Brief information on experimental locations and data availability for the study is given in Table 8. Among the selected study locations, Akola and Parbhani are located in Vidarbha and Marathwada regions respectively, in Maharashtra state. Cotton, sorghum, soybean, pigeon pea and other pulses are the main kharif crops, while wheat, sorghum and gram are major rabicrops grown in these regions. Soil moisture will be sufficient for short duration crops, while for long duration cops like pigeon pea, cotton etc., the crop suffers from moisture stress during physiological maturity 39,40 which necessitating studies on soil water balance, crop-water relations. Ananthapuramu is located in the dry plains of south western of Andhra Pradesh and Bengaluru falls under eastern dry zone of Karnataka. Anantapuramu fails to receive rains from both SW and NE monsoon due to obstruction caused by Eastern Ghats of Tamil Nadu and Western Ghats of Karnataka ${ }^{41}$. The major crops grown in these two regions are pigeon pea, groundnut, sunflower, rice, cotton, maize, chillies, sesame, finger millet and sugarcane. Usually, these crops are sown immediately after onset of monsoon rainfall i.e. in the month of June-July. The crops may make full use of available soil moisture at early stages (JulySeptember) to attain vegetative and reproductive stage, however, may suffer moisture deficit at late maturity stages due to decrease in rainfall, leading to yield loss. Kovilpatti is situated in the midst of the vertisol belt on the southern agro-climatic zone of Tamil Nadu. It is characterized by least rainfall receiving area in the state ${ }^{42}$, receives $646.8 \mathrm{~mm}$ annual rainfall $(29 \% \mathrm{CV}$ ) and in which only $60 \mathrm{~mm}$ of which falls during four months of monsoon season. $427.7 \mathrm{~mm}$ of rain falls during Northeast monsoon period (October - December). The geographical locations and selected crops of the study area are depicted in Fig. 7. The understanding of spatiotemporal heterogeneity in rainfall over the five selected locations helps to understand the interactions between crop and environment ${ }^{43}$. The impact of rainfall on soil moisture is related to the change of the soil moisture field, which is dominated by the water-diffusing mechanism, surface run-off or diffusion through the medium during the rainy period. It is also observed that the correlation time of the rainfall is much smaller than that of the soil moisture field. This obviously limits the impact of the rainfall on the soil moisture field variability ${ }^{44}$. 
Table 8

Crops under study and dataset availability at the study locations. FC: Field capacity, PWP: Permanent Wilting Point.

\begin{tabular}{|c|c|c|c|c|c|c|c|c|c|}
\hline \multirow[t]{2}{*}{ Location } & \multirow[t]{2}{*}{ Crop } & \multirow{2}{*}{$\begin{array}{l}\text { Study } \\
\text { period }\end{array}$} & \multicolumn{2}{|c|}{ Crop data } & \multicolumn{4}{|c|}{ Weekly Soil moisture data } & \multirow{2}{*}{$\begin{array}{l}\text { Soil } \\
\text { type }\end{array}$} \\
\hline & & & $\begin{array}{l}\text { Growth } \\
\text { stages }\end{array}$ & $\begin{array}{l}\text { Date } \\
\text { of } \\
\text { sowing }\end{array}$ & $\begin{array}{l}\text { Depth } \\
\text { (cm) }\end{array}$ & $\begin{array}{l}\text { Depth } \\
\text { (cm)x } \\
\text { number } \\
\text { of } \\
\text { depths }\end{array}$ & $\begin{array}{l}\text { FC } \\
(\%)\end{array}$ & $\begin{array}{l}\text { PWP } \\
(\%)\end{array}$ & \\
\hline Akola & Soybean & $\begin{array}{l}2008- \\
18\end{array}$ & NA & 4 & 30 & $15 \times 2$ & 32.8 & 14.2 & Vertisol \\
\hline Ananthapuramu & Groundnut & $\begin{array}{l}2009 \\
2012- \\
16\end{array}$ & 6 & 3 & 40 & $10 \times 4$ & 34.0 & 9.0 & Alfisol \\
\hline \multirow[t]{3}{*}{ Bangalore } & $\begin{array}{l}\text { Finger } \\
\text { millet }\end{array}$ & $\begin{array}{l}2014- \\
19\end{array}$ & 3 & 1 & 30 & $15 \times 2$ & 22.0 & 8.0 & Alfisol \\
\hline & Groundnut & $\begin{array}{l}2014- \\
19\end{array}$ & 3 & 2 & 45 & $15 \times 3$ & & & \\
\hline & Pigeonpea & $\begin{array}{l}2014- \\
19\end{array}$ & 3 & 3 & 60 & $15 \times 4$ & & & \\
\hline Kovilpatti & Maize & $\begin{array}{l}2008- \\
19\end{array}$ & 3 & 1 & 45 & $15 \times 3$ & 35.0 & 14.0 & Vertisol \\
\hline \multirow[t]{2}{*}{ Parbhani } & Soybean & $\begin{array}{l}2013- \\
18\end{array}$ & 3 & NA & 60 & $15 \times 4$ & 33.3 & 13.3 & Vertisol \\
\hline & Cotton & $\begin{array}{l}2014- \\
18\end{array}$ & 3 & 4 & 60 & $15 \times 4$ & & & \\
\hline
\end{tabular}

\section{Climatic and soil characteristics of the study area}

All the locations fall under typical Indian monsoon climate, characterised by two peaks of rainfall during southwest monsoon (June to September) and north-east monsoon (October to December) ${ }^{45}$. Daily rainfall data of these locations during the study period was obtained from automatic weather stations (AWS) located in each centre. The mean monthly and seasonal rainfall along with coefficient of variation of these locations during the study period is furnished in Fig. 8.

The soils of the study locations were grouped into two broad categories; vertisols (Akola, Parbhani and Kovilpatti) and alfisols (Ananthpuramu and Bangalore) ${ }^{46}$. Vertisols of Akola and Parbhani are deep, calcareous, clayey and very dark greyish brown to dark brown in colour, with low electrical conductivity (EC $\left.\leqslant 2 \mathrm{dS} \mathrm{m}^{-1}\right)$, alkaline and have exchangeable sodium percentage (ESP) less than 5 . The soils are characterised by presence of deep cracks during summer (low rainfall periods) due to the swelling and shrinkage property of the clay in the soil $^{47}$ which helps in soaking of deeper layers of soil soon after receipt of rainfall. Whereas, vertisols of Kovilpatti are clay loam, alkaline $\left(\mathrm{pH}\right.$ : 8.04) and had low EC $\left(0.45 \mathrm{dS} \mathrm{m}^{-1}\right)$ and not as deep as black cotton soils of other two vertisols under study ${ }^{48}$. Alfisols of Bangalore and Ananthapuramu are sandy clay loam in texture, 
acidic ( $\mathrm{pH}$ : 5.0-6.5), low in electrical conductivity $\left(0.09 \mathrm{dS} \mathrm{m}^{-1}\right)$ even the clay content is high, the soil fails to supply enough moisture throughout the crop growth period due to poor infiltration of rainfall because of surface crusting $^{49}$.

\section{Estimation of soil moisture}

Soil moisture is one of the several factors has major role in maintaining plant water relationships and hence influencing crop growth ${ }^{50}$. It constrains plant transpiration and photosynthesis, with consequent impacts on the water, energy and biogeochemical cycles. Soil moisture is usually defined as the water contained in the unsaturated soil zone ${ }^{51}$. Generally, it is measured gravimetrically using the following formula and can be expressed volumetrically.

\section{Soil moisture $(\%)(\theta \mathrm{m})=\frac{\mathrm{Wf}-\mathrm{Wd}}{\mathrm{Wd}} * 100$}

Where, $\mathrm{Wf}=$ Fresh weight of the sample, $\mathrm{Wd}=$ Dry weight of the soil sample

The volumetric water content $(\theta v)$ can be calculated by employing the following equation,

$$
\theta v=\frac{\frac{M w}{\rho w}}{V s}
$$

Where, $\rho w$ is the density of water (typically assumed to be $1 \mathrm{Mg} \mathrm{m}^{-3}$ ), Mw is the mass of water content and Vs is the volume of the soil. The $\theta v$ and $\theta \mathrm{m}$ are related by the soil bulk density ( $\rho b)$, which is the dry weight of soil per unit volume of field soil. $(\rho b=\mathrm{Md} / \mathrm{Vs})$.

In order to estimate the water availability at root zone, the information on root depth of the crop and multiple samples of at the rooting depth is required since, the rooting depth varies widely for different crops and crop stages. The rooting depth varies from 0.1-0.5 $\mathrm{m}$ for garden crops to several metres for perennial trees. The information of below soil surface is also critical since rooting depth maybe restricted by physical barriers like rock layers or the chemical properties viz., high $\mathrm{pH}$, Boron and salinity. Hence, soil water measures should be taken at several depths, since water content usually varies with depth within the root zone ${ }^{52}$.

The root zone water content (Wrz) can be calculated as cumulative sum of $\theta v$ at each depth multiplied by the depth of soil layer as follows.

\section{$\mathrm{Wrz}=\theta \mathrm{vd} 1+\theta \mathrm{vd} 2+\theta \mathrm{vd} 3+\cdots+\theta \mathrm{vdn}$}

Where, $\theta v 1, \theta v 2 \theta v 3$ and $\theta v n$ are volumetric water contents at soil depths representing the root zone; d1, d2, d3 and $\mathrm{dn}$ represent the thickness of each of soil layers sampled.

\section{Calculation of PASM}


The per cent available soil moisture is used as one of the impact indicators (triggers) in declaration of agricultural drought ${ }^{8}$. As per the drought manual published by Ministry of Agriculture and Farmers' Welfare, Government of India. It (PASM) was calculated using observed moisture data or soil-water balance model following the 'bucket approach' and it was calculated using the following formula,

$$
\operatorname{PASM}(\%)=\frac{\mathrm{SMW}-\mathrm{PWP}}{\mathrm{FC}-\mathrm{PWP}} * 100
$$

Where, SMW = Weekly calculated volumetric soil moisture (vol/vol) for the current week PWP = Permanent wilting point of the soil ( $\mathrm{vol} / \mathrm{vol}) \mathrm{FC}=$ Field capacity of soil ( $\mathrm{vol} / \mathrm{vol}$ )

\section{Development of relationship between crop yield and PASM}

Consider a crop grown in a particular season, sown in different dates of sowing. In each date of sowing, weekly soil moisture observations were taken and PASM was calculated. These weekly observations were classified according to existing ranges as follow.

\begin{tabular}{|ll|}
\hline PASM (\%) & Agricultural Drought Class \\
\hline $76-100$ & No drought \\
\hline $51-75$ & Mild drought \\
$26-50$ & Moderate drought \\
$<25$ & Severe drought \\
\hline
\end{tabular}

Since the crop is grown under different dates of sowings, early sown crop may experience drought lately at reproductive or maturity stages and late sown crop may experience mid-season drought. Such data on long term experiments provide a base to understand the crop performance under various drought or moisture stress scenarios at different growth stages of the crop. Likewise, data from long term experiments were collected and grouped into 4 groups $(0-25,26-50,50-75$ and $75-100)$ according to existing classes of PASM for drought declaration (in each growth stage of the crop i.e. vegetative, reproductive, maturity and harvest).

For each crop, regression equations were developed between percent available soil moisture and yield. Best fitting (in terms of R2 value) equations were chosen to find the yield of crop at a particular PASM and PASM required for obtaining $50 \%$ of the optimal yield. Optimum yields are estimated by averaging crop yields at university and farmers' field, half of that yield (i.e. 50\%) is substituted to ' $y$ ' value of the developed regression equation to find ' $x$ ' at that level of ' $y$ '.

The hypothesis behind estimating PASM requirement for $50 \%$ of optimal yield is that, if a farmer gets at least $50 \%$ of yield, he will be able to meet out the expenses of cost of cultivation, thereby helping him to get rid of farm debt related financial crisis. Hence, the PASM-yield relationship establishment in individual crop lays a scientific base for timely and appropriate drought declaration thereby helping economically meaningful relief assistance.

\section{Declarations}




\section{Author contributions}

S.K.B, H.S.S and P.V.K. conceived, designed the study and prepared the manuscript; H.L, V.M.S. and A.V.M.S.R did the analysis and edited the manuscript; V.K.S. have provided the supervision and guidance for the analysis and preparation of manuscript; M.H.M, S.N.M, A.T., G.S., K.K.D and S.S have done the field experiments at the study locations and prepared the data sets used for the analysis of this work. All the authors jointly developed the final set of analyses and contributed to the writing and editing of the manuscript.

\section{Statement for institutional, national \& international guidelines}

During the conduct of field studies on cultivated plants and collection of plant material from the experiments, we followed the national guidelines and legislation.

\section{References}

1. McCarthy, J.J., Canziani, O.F., Leary, N.A., Dokken, D.J. \& White, K.S. (eds) Climate change 2001: impacts, adaptation and vulnerability. Cambridge University Press, Cambridge (2001).

2. Ritchie, J.T. Efficient water use in crop production: discussion on the generality of relations between biomass production and evapotranspiration. (ed. Taylor, H.M., Jordan, W.R., Sincliar, T.R.) Limitations to efficient water use in crop production, 29-44, American Society of Agronomy, Madison, WI, USA, (1983).

3. Thomson, A.M., Izaurralde, R.C., Rosenberg, N.J. \& Xiaoxia H. Climate change impacts on agriculture and soil carbon sequestration potential in the Huang-Hai Plain of China. Agric. Ecosyst. Environ., 114 (4), $195-$ 209, DOI: https://doi.org/10.1016/j.agee.2005. 11.001 (2003).

4. Zhang, X., Obringer, R. \& Wei, C. Droughts in India from 1981 to 2013 and Implications to Wheat Production. Sci. Rep., 7, 44552, DOI: https://doi.org/10.1038/srep44552 (2016).

5. Khanday, M.Y. \& Javed, A. Impact of climate change on land use or land cover using remote sensing and GIS in Chopal watershed, Guna, Madhya Pradesh (India). J. Environ. Res. Develop., 2, 568-579 (2008).

6. Shewale, M.P. \& Shravan Kumar. Climatological features of drought incidences in India. Meteorological Monograph Climatology, 1-24, (IMD 2005).

7. Neenu, S., Biswas, A.K. \& Subba Rao, A. Impact of climatic factors on crop production - A review. Agri. Reviews. 34 (2), 97-106 (2013).

8. Anonymous. Manual for drought management, 37-39, Department of Agriculture, Cooperation \& Farmers Welfare, Ministry of Agriculture \& Farmers Welfare Government of India (2016).

9. Palmer, W.C. Meteorological drought, 58 pp., Office of Climatology Research Paper 45, Weather Bureau, Washington, D.C (1965).

10. Gibbs, W.J. \& Maher, J.V. Rainfall Deciles as Drought Indicators. Bureau of Meteorology Bulletin No. 48, Melbourne, Australia (1967).

11. Shafer, B.A. \& L.E. Dezman, L.E. Development of a Surface Water Supply Index (SWSI) to Assess the Severity of Drought Conditions in Snowpack Runoff Areas. 164-175, Proceedings of the Western Snow Conference, Colorado State University, Fort Collins, CO (1982). 
12. McKee, T.B., Doesken, N.J. \& Kleist, J. The relationship of drought frequency and duration to time scales. 179-184. Proceeding of the $8^{\text {th }}$ Conference on Applied Climatology. American Meteorological Society: Boston (1993).

13. Byun, H.R. \& Wilhite, D.A. Objective quantification of drought severity and duration. J. Clim., 12, 2747-2756, DOI: https://doi.org/10.1175/1520-0442(1999)012<2747: OQODSA>2.0.C0;2 (1999).

14. Tsakiris, G. \& Vangelis, H. Establishing a Drought Index Incorporating Evapotranspiration, Eur. Water, 9-10, 311 (2005).

15. Vicente-Serrano, S.M., Beguería, S. \& López-Moreno, J.I. A multi-scalar drought index sensitive to global warming: the standardized precipitation evapotranspiration index - SPEI. J. Clim. 23, 1696-1718, DOI: https://doi.org/10.1175/2009JCLI2909.1 (2010).

16. Yue, W., Xu, J., Tan, W. \& Xu, L. The relationship between land surface temperature and NDVI with remote sensing: application to Shanghai Landsat 7 ETM+ data. Int. J Remote. Sens. 28(15), 3205-3226, DOI: https://doi.org/10.1080/01431160500306906 (2007).

17. Gao, B.C. NDWI - A normalized difference water index for remote sensing of vegetation liquid water from space. Remote Sens. Environ, 58, 257-266, DOI: https://doi.org/10.1016/S0034-4257(96)00067-3 (1996).

18. Palacios-rueta, A., Khanna, S., Litago, J., Whiting, M.L. \& Ustin, S.L. Assessment of NDVI and NDWI spectral indices using MODIS time series analysis and development of a new spectral index based on MODIS shortwave infrared bands. 207-209, Proceedings of the 1st International Conference of Remote Sensing and Geoinformation Processing; Trier, Germany (2006).

19. Denmead, O.T. \& Shaw, R.H. The effects of soil moisture stress at different stages of growth on the development and yield of corn. Agron. J. 52(5), 272-274, DOI:

https://doi.org/10.2134/agronj1960.00021962005200050010x (1960).

20. Bharat, S.A. et al. Winter cover crops effect on soil moisture and soybean growth and yield under different tillage systems. Soil. Tillage Res. 195, 167-187, DOI: https://doi.org/10.1016/j.still.2019. 104430 (2019).

21. Decker, W.L., Jones, V.K. \& Achutuni, R. The impact of climatic change from increased atmospheric carbon dioxide on American agriculture. DOE/NBB-0077, Dep. of Atmos. Sci., Univ. of Missouri, Columbia, MO (1986).

22. Machado, S., Bynum, E.D. \& Archer, T.L. Spatial and Temporal Variability of Sorghum Grain Yield: Influence of Soil, Water, Pests, and Diseases Relationships. Precision Agric. 3, 389-

406, https://doi.org/10.1023/A:1021597023005 (2002).

23. Stephens, D.J. \& Lyons, T.J. Rainfall-yield relationships across the Australian Wheat belt. Aust. J. Agric. Res. 49, 211-224 (1998).

24. Doorenbos, J. \& Pruitt, W.O. Guidelines for predicting crop water requirements. FAO Irrig. Drain. Pap. 24,193 pp. Food and Agric. Organization of the United Nations, Rome, Italy (1977).

25. Betts, A.K. Understanding hydrometeorology using global models. Bull. Am. Meteorol. Soc. 85(11), 16731688, DOI: https://doi.org/10.1175/BAMS-85-11-1673 (2004).

26. Robel, A., Abraham, W.M. \& Tilahun, H. Effect of Moisture Stress on Maize (Zea Mays L.) Yield and Water Productivity. Int. J. Environ. Sci. Nat. Res. 16(4), 83-87, DOI: 10.19080/IJESNR.2019.16.555945 (2019).

27. Iliana, E. M. et al. Inter-comparison of soil moisture, evaporative stress, and vegetation indices for estimating corn and soybean yields over the U.S. J. Applied Earth Obs. Remote Sens. 10(4), 1328-1343, DOI: 
10.1109/JSTARS.2016.2639338. (2017)

28. Rohit, P. et al. Potential impact of future climate change on maize (Zea mays L.) under rainfed condition in central India. J. Agrometeorol., 22 (1), 18-23 (2020).

29. Eck, H.V. Effects of water deficits on yield, yield components, and water use efficiency of irrigated Corn. Agron. J., 78(6), 1035-1040, DOI: https://doi.org/10.2134/agronj1986. 00021962007800060020x (1986).

30. Maqsood, M. \& Azam Ali, S.N. Effects of drought on growth, development, radiation use efficiency and yield of finger millet (Eleucine coracana). Pak. J. Bot., 39(1), 123-134 (2007).

31. Staton, M. Moisture stress and high temperature effects on soybean yields. 1-25 pp. Annual reports, Michigan State University Extension. (2020).

32. Guled, P. M., Shekh, A. M., Patel, H. R. \& Pandey V. Effect of soil moisture, evapotranspiration, stress degree days on pod yield of groundnut (Arachishypogaea L). J. Agrometeorol., 15 (2), 135-137 (2013).

33. Pettigrew, W.T. Physiological consequences of moisture deficit stress in cotton. Crop Science, 44(4), 12651272, https://doi.org/10.2135/cropsci2004.1265 (2004).

34. Lopez, F.B., Johansen, C. \& Chauhan, Y.S. Effects of timing of drought stress on phenology, yield and yield components of short-duration pigeon pea. J. Agron. Crop Sci. 177, 311-320, DOI: https://doi.org/10.1111/j.1439-037X.1996.tb00251.x (1996).

35. Subbareddy, G., Maruthi, V. \& Vanaja, M. Effect of soil depth on productivity of sorghum (Sorghum bicolor) and pigeonpea (Cajanus cajan) in sole and intercropping systems. Indian J. Agric. Sci., 71 (8), $510-515$ (2001).

36. Laszlo, M. Climate Change: Precipitation and Plant Nutrition Interactions on Potato (Solanum tuberosum L.) Yield in North-Eastern Hungary. 1398 pp. EGU General Assembly Conference Abstracts (2009).

37. Islam, M.S., Siddique, M.R. \& Hamid, A. Drought stress effects on photosynthetic rate and leaf gas exchange of wheat. Bot. Bull. Acad. Sin., 40, 141-145 (1999).

38. Tanin, Y. Estimation of wheat production with meteorological parameters, 23-25 pp. XXIII. World meteorology day agricultural meteorology seminar bulletin (1983).

39. Ashok, S. Environment and crop water requirement in districts of Maharashtra. 78-85. International epublication, International science congress association (2013).

40. Parmeshwar D.U., Yutaka, I., Anthony, S.K. \& Sudhindra, N.P. Drought impacts and adaptation strategies for agriculture and rural livelihood in the Maharashtra state of India. Open Agric. Journal. 8, 41-47,

DOI: 10.2174/1874331501408010041 (2014).

41. Waghaye, A.M., Rajwade, Y.A., Randhe, R.D. \& Kumari, N. Trend analysis and change point detection of rainfall of Andhra Pradesh and Telangana, India. J. Agrometeorol., 20(2), 160-163 (2018).

42. Anonymous. Observed Rainfall Variability and Changes over Tamil Nadu state. 1-25. Meteorological monograph, IMD (2020)

43. Bal, S.K. \& Minhas, P.S. Atmospheric Stressors: Challenges and Coping Strategies. In: "Abiotic Stress Management for Resilient Agriculture". (Eds. P.S. Minhas et al.). pp. 9-50, Springer Nature Singapore Pte. Ltd (2017).

44. Chulsang, Y., Juan, B.V. \& Gerald, R.N. Evaluation of the impact of rainfall on soil moisture variability. Adv. Water Resour. 21, 315-384 (1998). 
45. Parthasarathy, B., Munot, A.A. \& Kothawale, D.R. Monthly and seasonal rainfall series for all-India homogeneous regions and meteorological subdivisions: 1871-1994, IITM Research Report-065, Indian Institute of Tropical Meteorology, Pune, India (1995).

46. Chary, G.R. et al. Resilient Crops and Cropping Systems to Cope with Weather Aberrations in Rainfed Agriculture. pp 3-4. CRIDA-NICRA Bulletin (2020).

47. Balpande, S.S., Deshpande, S.B. \& Pal, D.K. (1996), Factors and processes of soil degradation in vertisols of the Purna Valley, Maharashira, India. Land Degrad. Dev. 7, 313-324.

48. Bharathi, G., Joseph, M., Velayutham, A. \& Baskar, K. Plant Geometry, Macro and Micro Nutrients on Growth and Growth Analysis of Dual-Purpose Sorghum under Rainfed Vertisol Condition, Int. J. Adv. Agril. Sci. Tech., 5(7), 61-74 (2018).

49. Bhattacharyya T., Pal D.K., Chandran P. \& Ray S.K. Landuse, clay mineral type and organic carbon content in alfisols of tropical India. Clay Res., 24(2), 105-122 (2005).

50. Wei, J., Dickinson, R.E. \& Chen, H. A negative soil moisture-precipitation relationship and its causes. J. of Hydrometeorol., 9, 1364-1376, DOl: https://doi.org/10.1175/ 2008JHM955.1 (2008).

51. Hillel, D. Defining the soil moisture. Environmental Soil Physics. 771 pp. Academic Press, San Diego (1998).

52. Schenk, H.J. \& Jackson, R.B. Mapping the global distribution of deep roots in relation to climate and soil characteristics. Geoderma, 126(1-2), 129-140, DOI: https://doi.org/10.1016/j.geoderma.2004.11.018 (2005).

\section{Figures}




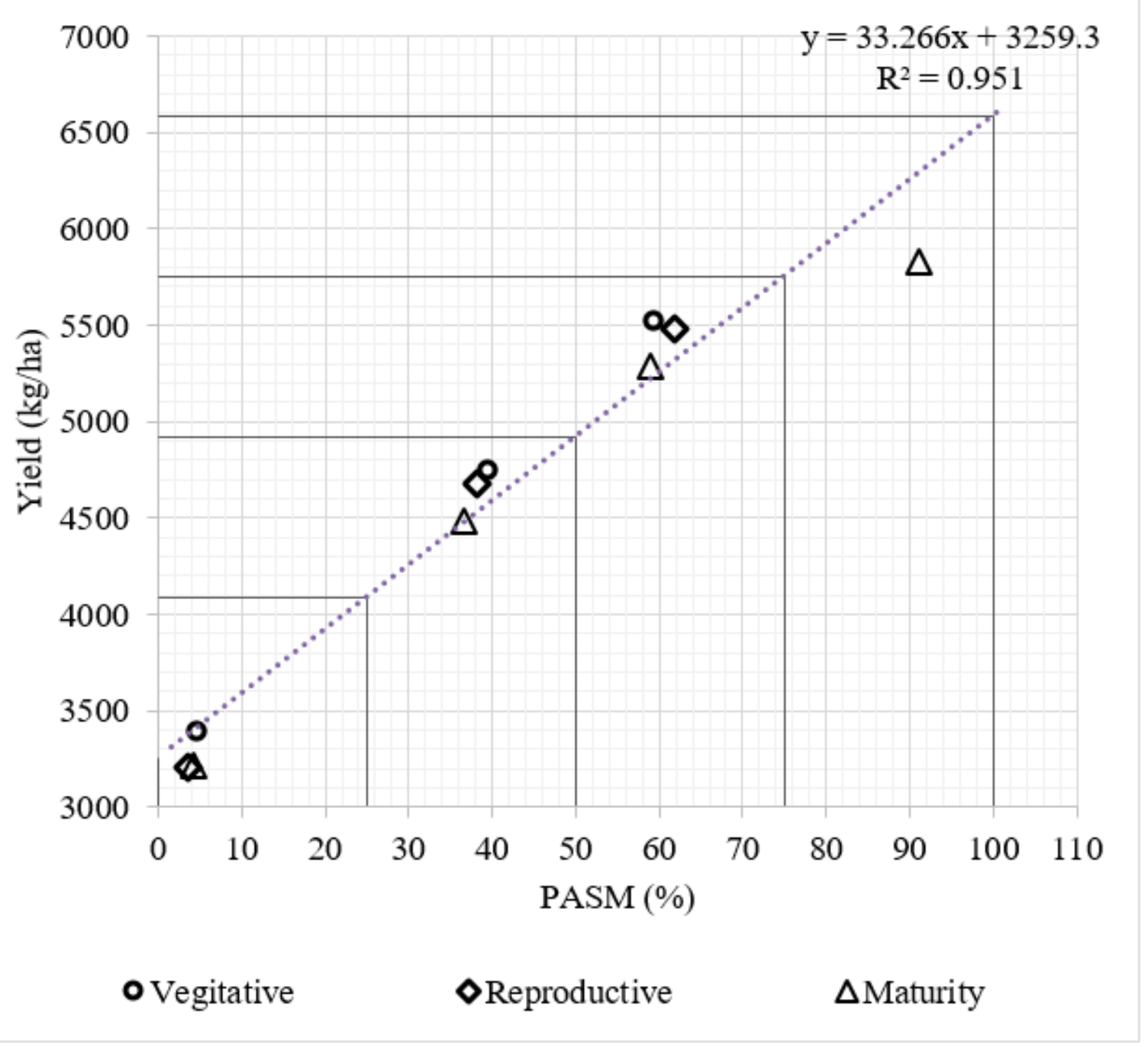

\section{Figure 1}

Yield variability in maize (Kovilpatti) with respect to available soil moisture in different growth stages. 


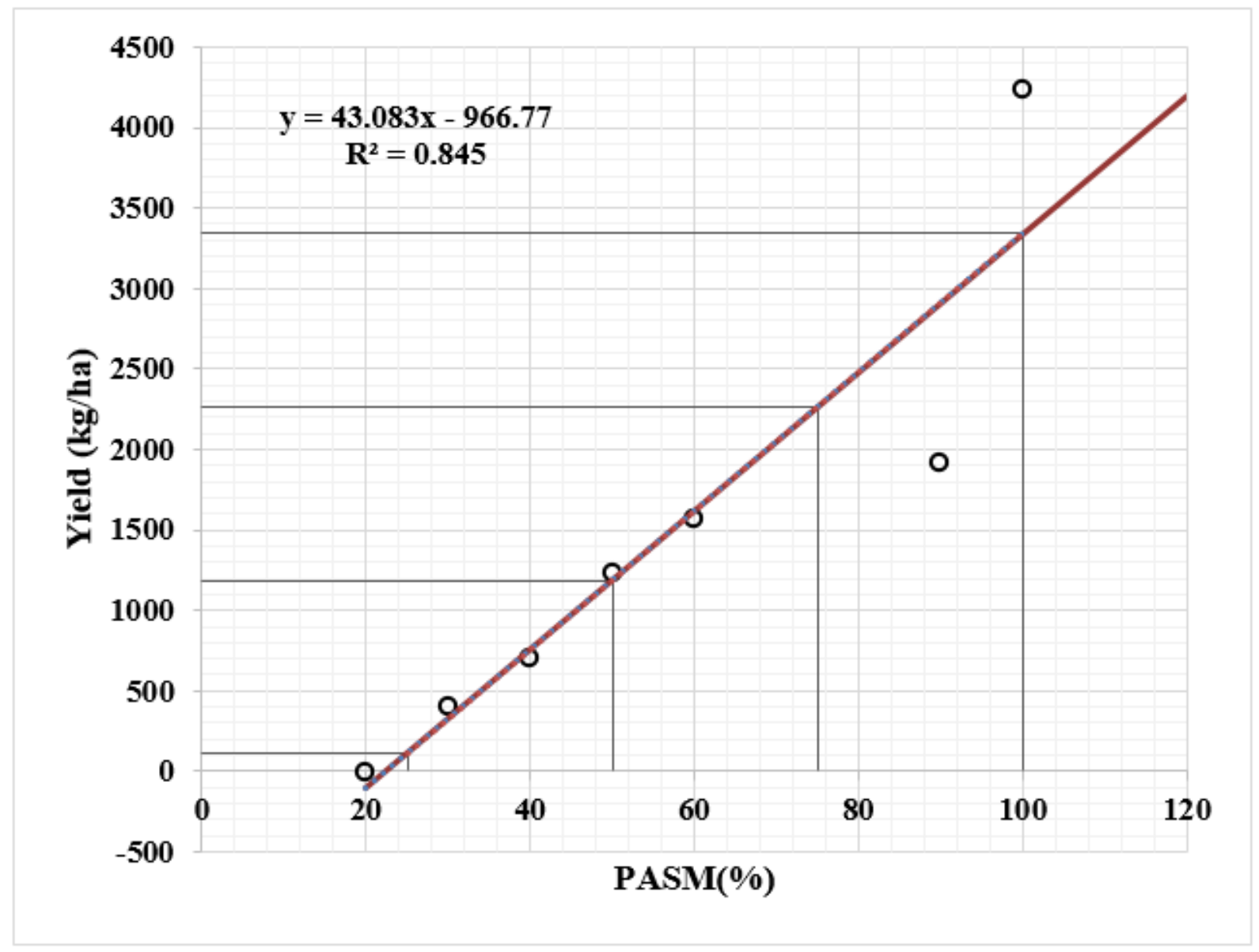

Figure 2

Yield variability in finger millet (Bangalore) with PASM. 


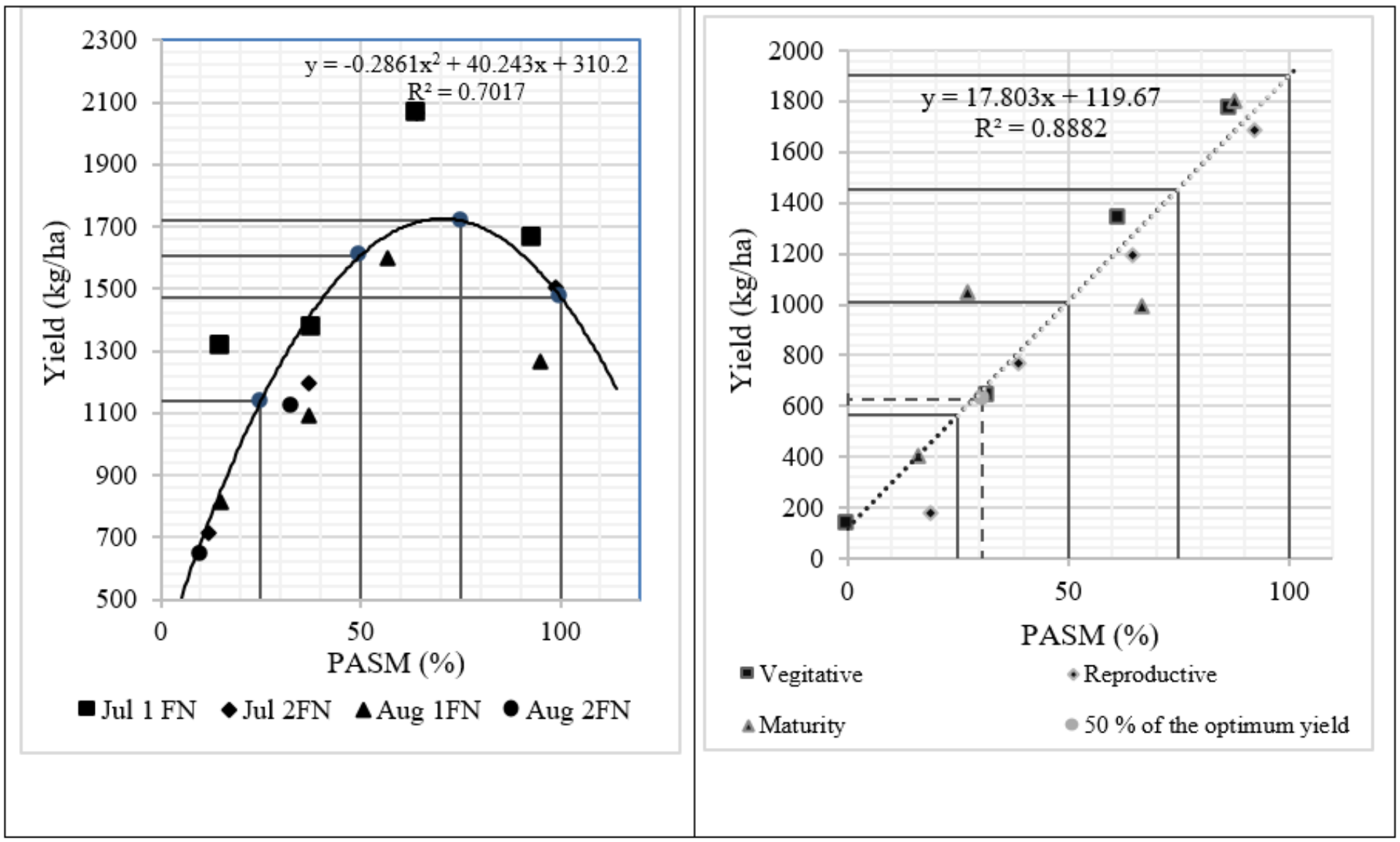

Figure 3

PASM and yield variability in soybean (left: Akola, right: Parbhani) in different sowing windows and growth stages.

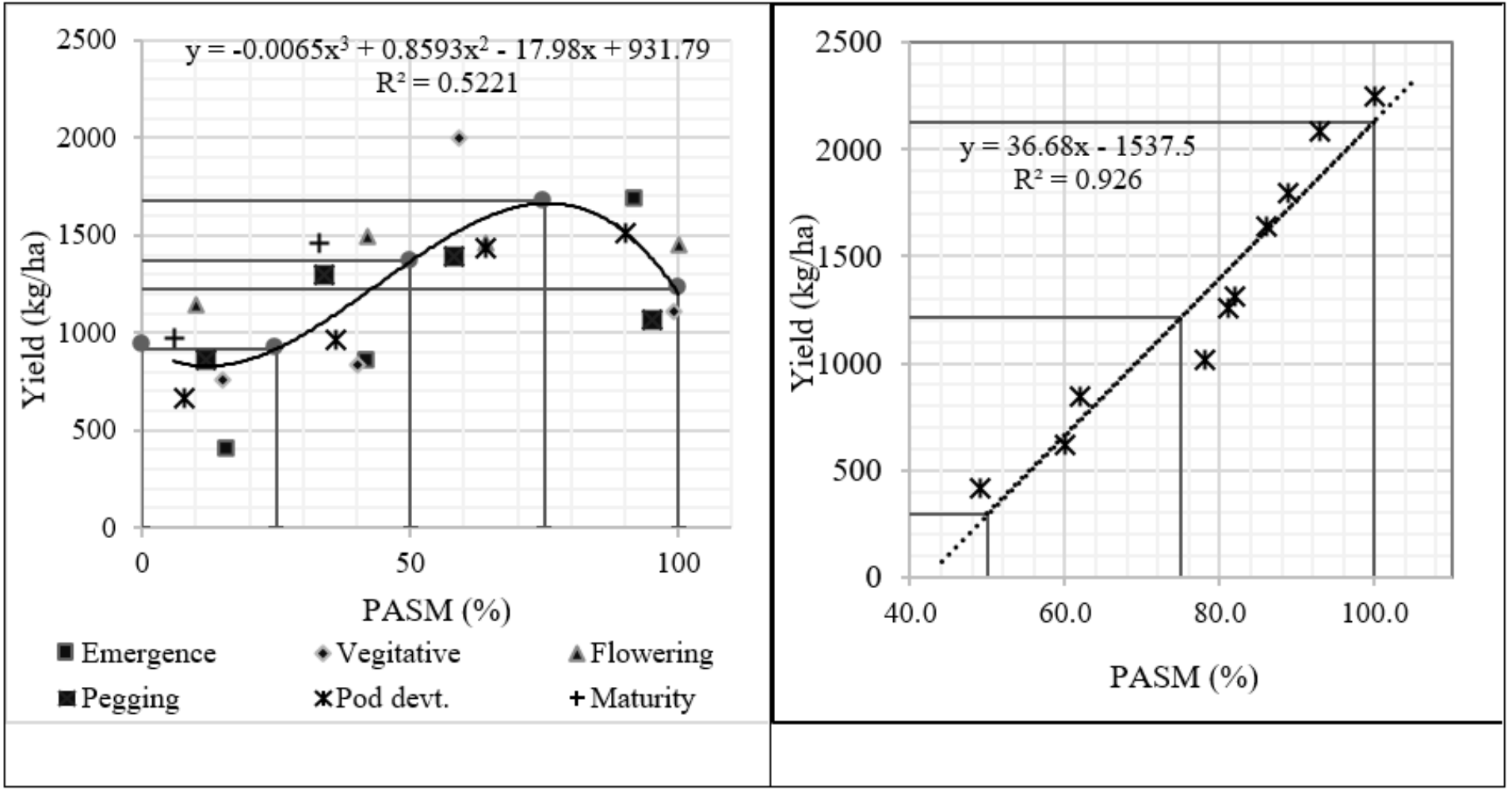


Figure 4

PASM and yield variability in groundnut at Ananthapuramu (left) and Bangalore (right).

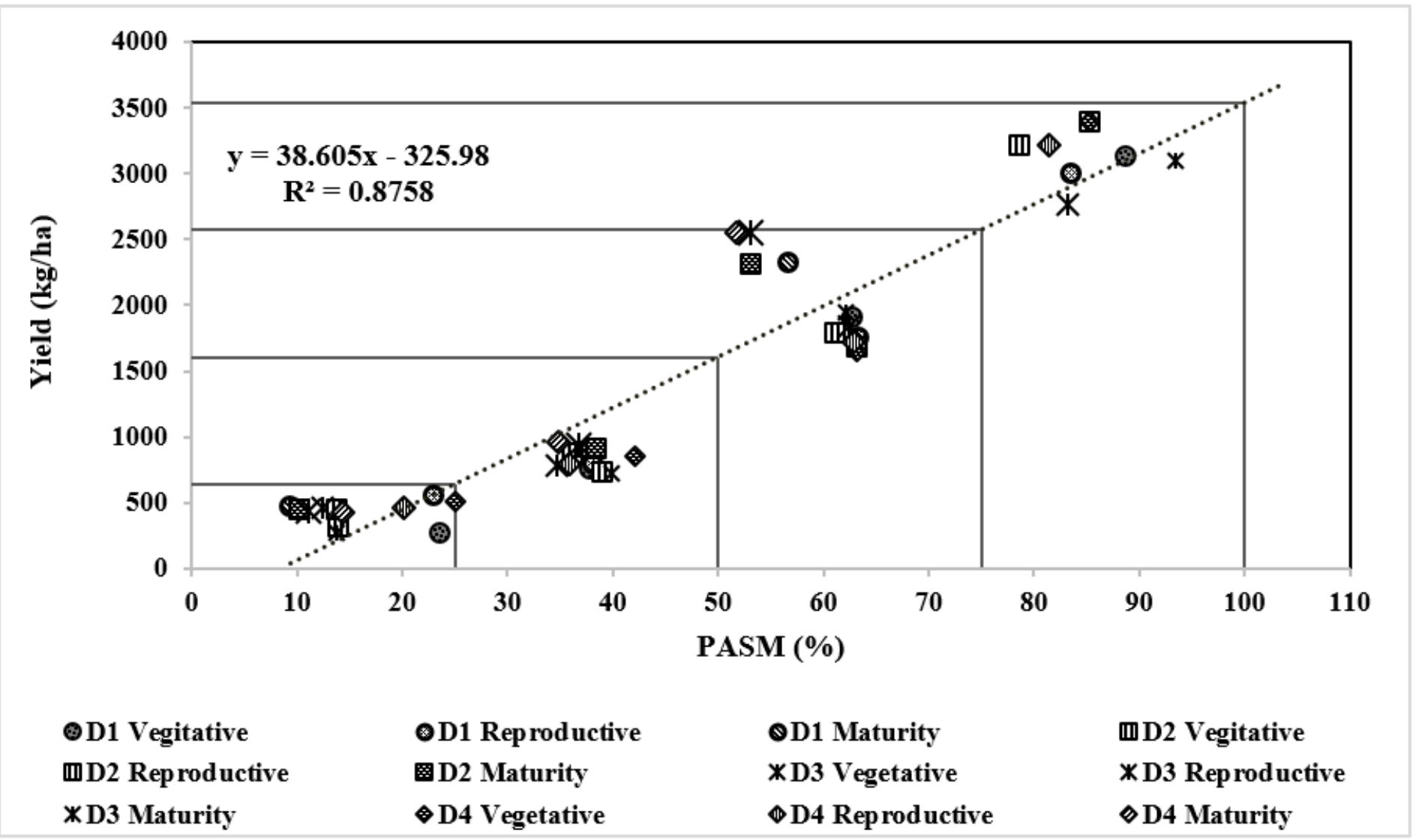

Figure 5

Yield variability in cotton with PASM at different growth stages under four sowing windows. Where, D1: June 2FN, D2: July 1FN, D3: July 2FN and D4: August 1FN 


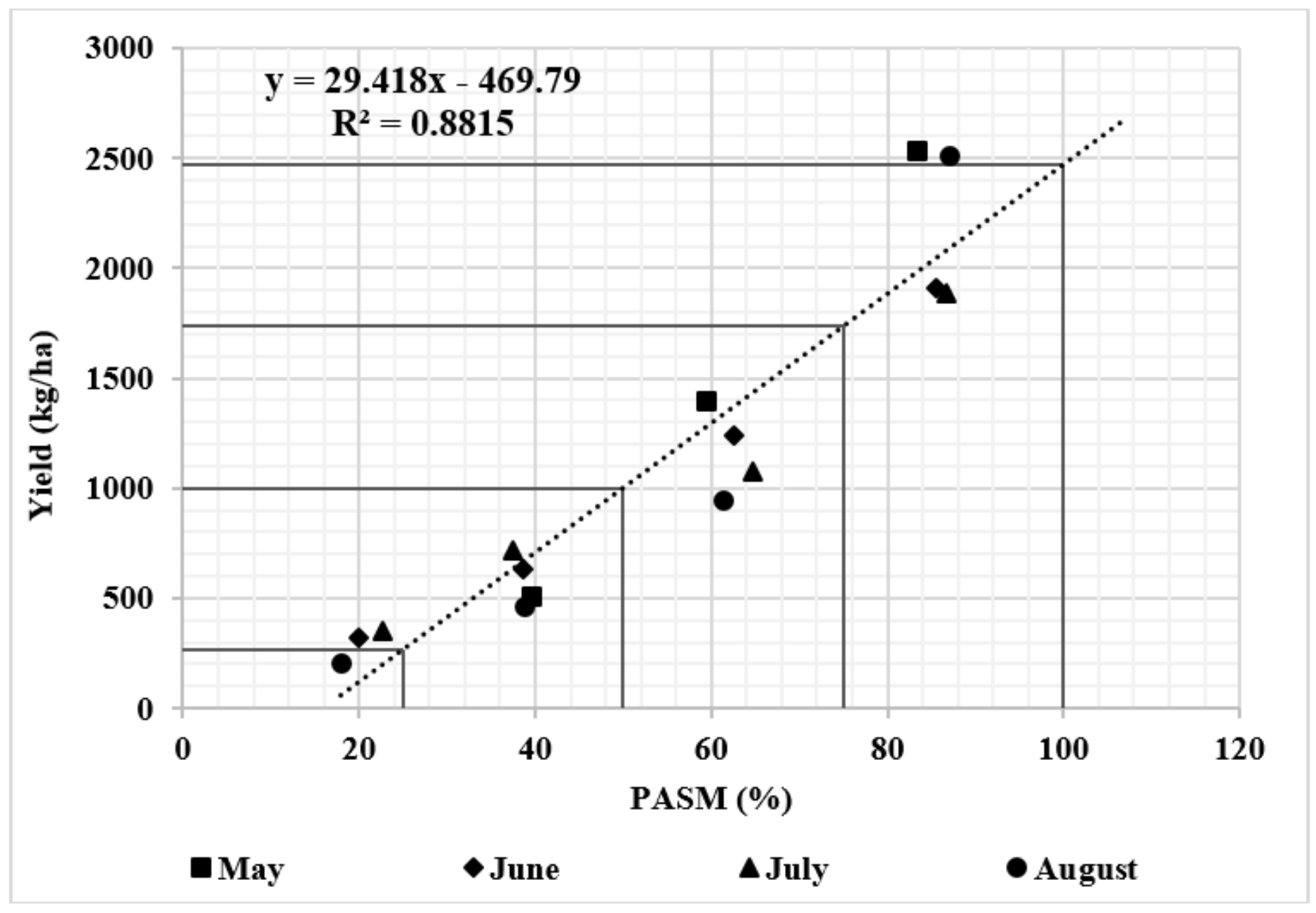

Figure 6

Yield variability in pigeon pea with PASM under 4 sowing windows. 


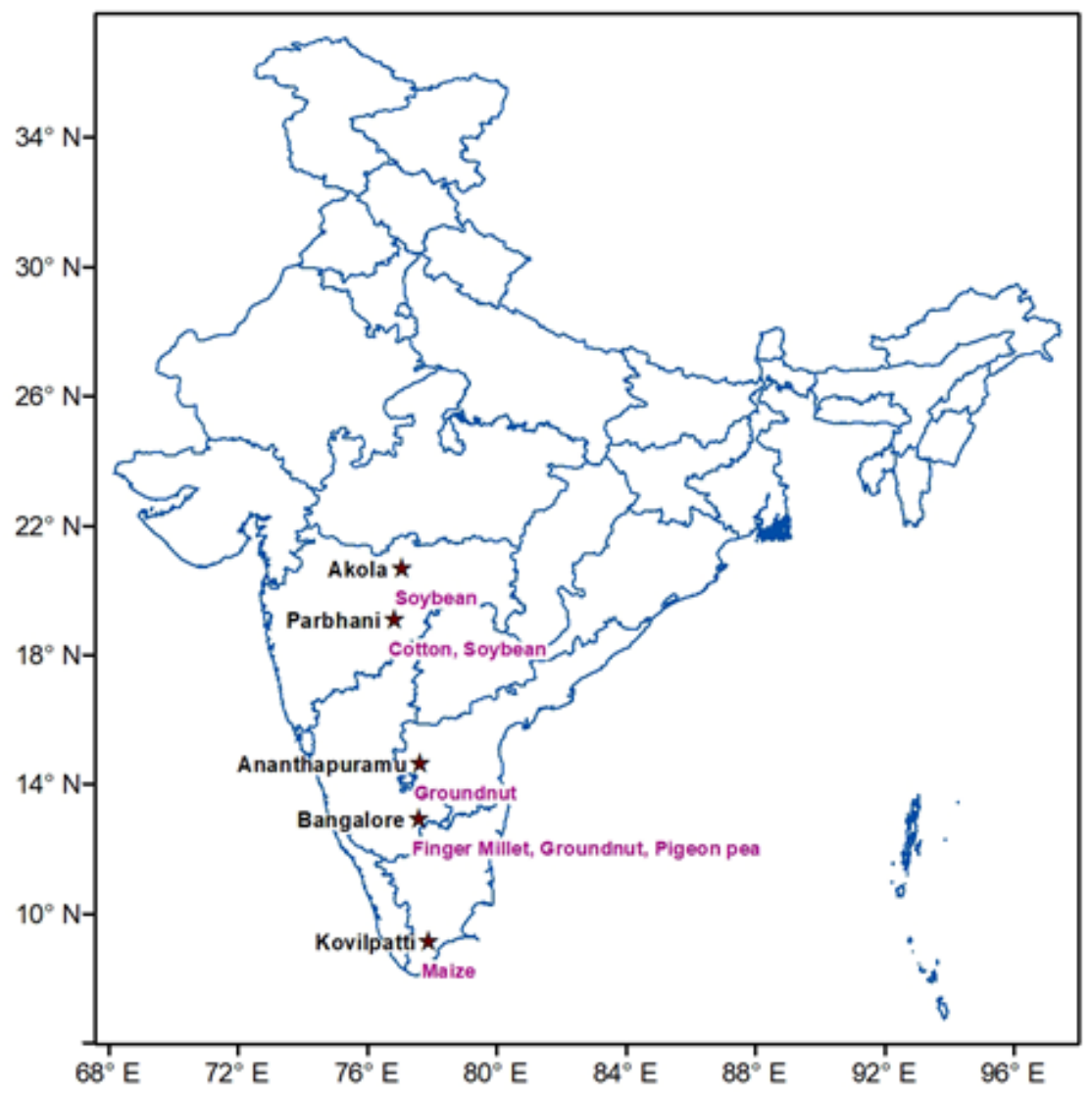

Figure 7

Geographical locations and selected crops of the study area

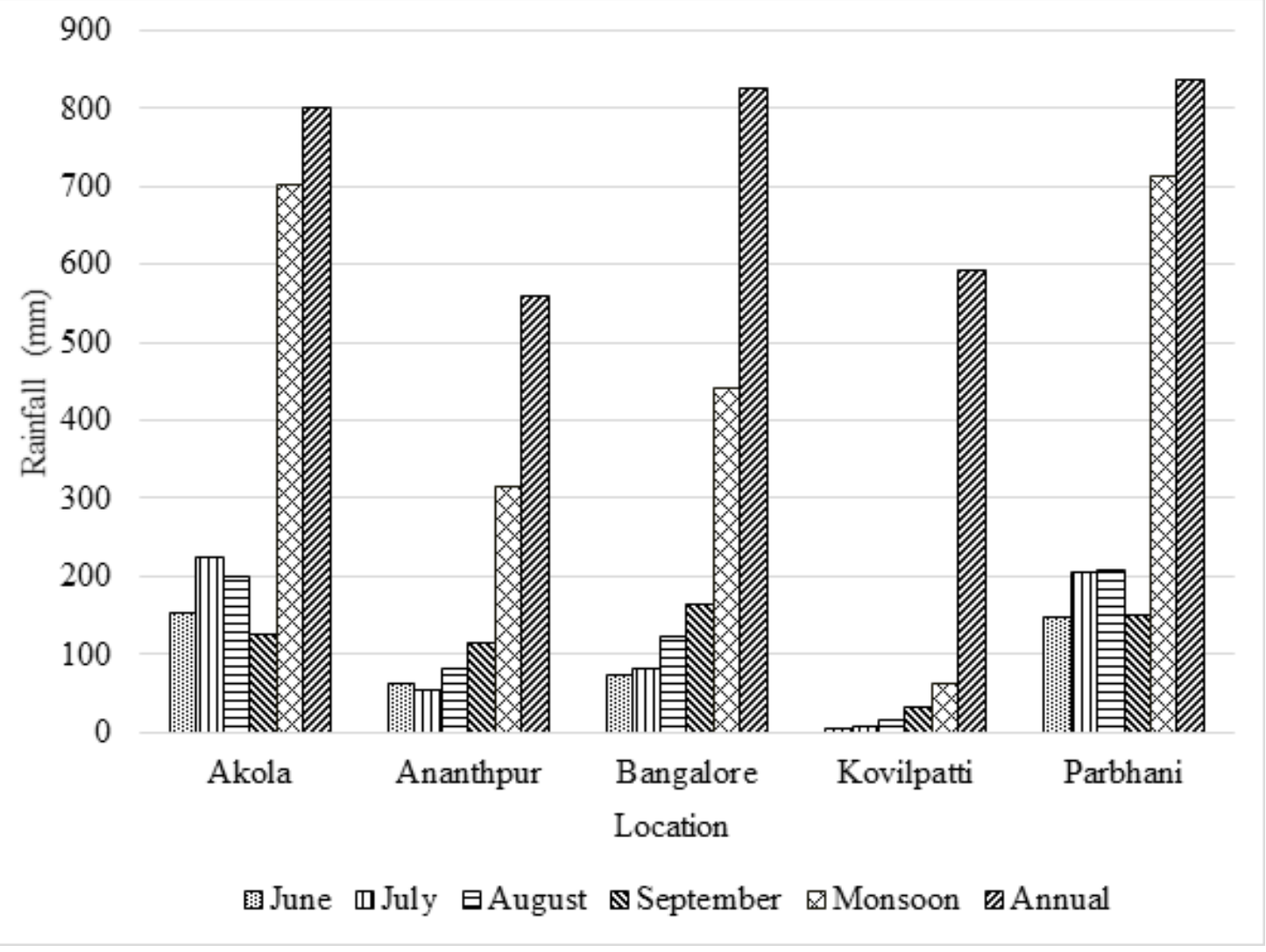




\section{Figure 8}

Mean monthly, monsoonal and annual rainfall (average of 30 years; 1989-2019) during monsoon period in different study locations (Labels on each pillar indicate the coefficient of variance in monthly rainfall). 